DOI: $10.20287 /$ ec.n24.a12

\title{
Digital democracy and political participation through Facebook: Portuguese legislative elections in 2015
}

\author{
Marlene Loureiro \& Joana Ribeiro \\ LabCom.IFP \& UTAD / UTAD, Portugal \\ E-mail: mloureiro@utad.pt / joana.23@hotmail.com
}

\begin{abstract}
In a time when new technologies are being used every day, it is natural that they are becoming instruments of political communication. In fact, since the 1990s, new digital devices have been used by political parties for their benefit. Based on this current reality, it was important to study the importance of the Internet for communication and political participation, especially during the electoral campaign for

ploratory study shows that, in fact, the electorate is aware of the importance of the Internet, especially of social networks as facilitating instruments for political participation. However, while it is common to speak of digital democracy, more than half of the respondents did not follow the 2015 election campaign through the tools and platforms provided on Internet by the political parties.
\end{abstract} the 2015 Legislative Elections in Portugal. This ex-

Keywords: political communication; Internet; digital democracy; political participation.

\section{Democracia digital e participação política através do Facebook: as eleições legislativas portuguesas em 2015}

\begin{abstract}
Resumo
Numa era onde as novas tecnologias são utilizadas por todos nós diariamente, é normal que estas se tenham transformado em instrumentos ao serviço da comunicação política. De facto, desde os anos 90 do século passado que os novos dispositivos digitais têm vindo a ser usados pelos partidos políticos em seu benefício. Perante esta realidade, é importante estudar a importância que a Internet têm para a comunicação e participação políticas, nomeadamente

durante a campanha eleitoral para as Eleições Legislativas de 2015 em Portugal. Este estudo exploratório revela que, de facto, o eleitorado tem consciência da importância da Internet, especialmente das redes sociais, enquanto ferramentas promotoras e facilitadoras da participação política. Contudo, embora seja comum falar-se em democracia digital, mais de metade dos inquiridos não seguiu a campanha eleitoral de 2015 através das ferramentas e plataformas dis-
\end{abstract}

Data de submissão: 2017-03-26. Data de aprovação: 2017-05-04.

A Revista Estudos em Comunicação é financiada por Fundos FEDER através do Programa Operacional Factores de Competitividade - COMPETE e por Fundos Nacionais através da FCT - Fundação para a Ciência e a Tecnologia no âmbito do projeto Comunicação, Filosofia e Humanidades (LabCom.IFP) UID/CCI/00661/2013.

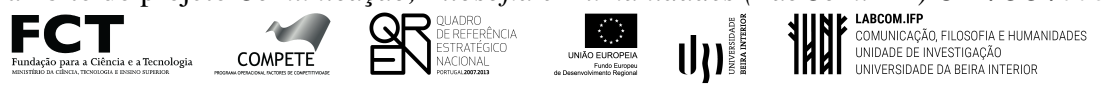


ponibilizadas pelos partidos políticos através da $I n$ -

ternet.

Palavras-chave: comunicação política; Internet; democracia digital; participação política.

\section{INTRODUCTION}

$\mathrm{T}_{\mathrm{N}}$ a time where new technologies are used by us every day, it is natural they are becoming 1 instruments at the service of political parties. In fact, since the 1990s new digital devices have been used by political communication for their benefit (Canavilhas, 2010, p.6). Nowadays, political communication uses the Internet to achieve its objectives, which reveals an enormous advantage of these digital devices in relation to traditional media (such as the mass media, election rallies, posters, etc.): citizens and the smaller political forces have greater freedom to express themselves (Rodrigues, 2009, p.3). In fact, political strategies have been changing in order to keep pace with new technologies. The Internet is already an important medium within political communication, which can and should be seen as means of expression and exercise of citizenship and of cyber democracy, if their interactive potentialities are well exploited (Rodrigues, 2009, p.3).

So, today we live in a digital democracy, which consists in the use of information and communication technologies (ICTs), through a variety of means, with the aim of increasing political democracy and citizen participation in issues related to democracy:

(...) the use of information and communication technology (ICT) and computer-mediated communication (CMC) in all kinds of media (e.g. the Internet, interactive broadcasting and digital telephony) for purposes of enhancing political democracy of the participation of citizens in democratic communication (Hacke \& Dijk, 2000, p.1)

Therefore, the new spaces for political discussion that take place on the Internet cannot be ignored (Rodrigues, 2009, p.4). In order for citizenship to exist, it is necessary to involve all the agents. The Internet is a good way to reach this end and, if used consciously, it becomes a great resource, a good tool, to foster interaction between civil society and politics (Sepúlveda, 2000, p.30). Sepúlveda (2000) even states that the Internet is the most democratic means we can have because it allows everyone to share with everyone the information they consider relevant. In addition, as already mentioned, it gives greater visibility to smaller parties that cannot be widely recognized on their own, mostly because of financial issues. This entire situation can stimulate politicians and citizens to participate more in politics, which may even reduce the rate of abstention (Sepúlveda, 2000, pp.29-32). It is therefore interesting to know in detail these new means of communication used by politics, but first of all we are going to look at the old media used.

\section{Political communication and Internet}

The media have always been linked to politics, since the emergence of press and the printed media, such as newspapers and books (Neder, 2001, p.20). The printed media, radio, television and, today, new technologies are the devices used by political communication. According to 
Canavilhas (2010), a device, in the scope of political communication, is any element that allows the politician to have contact with the voters, either individually or in a group (Canavilhas, 2010, p.4).

With the changes that have occurred within the scope of the instruments used during the electoral campaigns, we can distinguish between traditional devices and new devices. The traditional devices, according to Canavilhas (2000) are the various campaign mechanisms used by politicians in the pre-Internet era, many of them losing the importance of the past (Canavilhas, 2010, p.5), and they can be integrated into three groups: mass media, campaign actions, and propaganda.

\subsection{Political communication}

\subsubsection{The mass media}

The mass media are much used by politicians because of the power they have to influence the people. For this reason, politicians, and their advisors, need to look for ways to gain mass media attention. They choose to schedule conferences at the same time as television news to be able to appear live on television and they even hire militants to participate in radio forums and talk shows. In this way, politicians can gain visibility in the mass media, reaching a wide and heterogeneous audience with much reduced costs and without the mark of an election campaign action. In addition to the space that they can gain in this way, politicians also use the "Antenna right" space, something that has become less important because it is seen as "propaganda", gaining a negative reputation (Canavilhas, 2010, pp.5-6).

The emergence of the Internet has reduced the importance of printed media, radio and television as the main sources of information (Sorj, 2006, p.126). The Internet has brought with it an increase in citizens' knowledge about politics, which may lead to a change in voters' behaviour in elections (Rieffel, 2003, p.29) as it can help citizens to directly contact politicians to see which candidates they prefer to vote for.

\subsubsection{Campaign actions}

Campaign actions can be materialized in a variety of ways, such as rallies, colloquia, enlightenment sessions and visits to public places (Canavilhas, 2010, p.6). Originally, these actions aimed at direct contact with populations, but now they are another way to ensure coverage of the campaign by the mass media. These actions may be more or less important, depending on the type of campaign. For example, they will be more important in local elections, as the proximity to the public is high. The rallies have been losing relevance as they no longer truly show the strength of the campaigns in the various venues. Once politicians have begun to invite musicians and provide transport for people from other locations to a rally, no conclusions can be drawn about the strength of an application based on the number of people present at a rally. Canavilhas (2010) states that rallies are nowadays more a spectacle set for the media (Canavilhas, 2010, p.6) 


\subsubsection{Ways of propaganda}

There are various supports used by politicians in electoral campaigns, such as posters, pamphlets, stickers and gifts (Canavilhas, 2010, p.6). The outdoors are a traditional medium used as well as mobile advertising, which has shown good results because it can move around several places, which exposes a large number of people to the message to be sent (Simões et al., 2009, p.53). However, traditional outdoors have been replaced by the MUPIs ${ }^{1}$, a more ecological way of spreading the message (Canavilhas, 2010, p.6). Pamphlets are widely used because they are inexpensive because they can be produced in large quantities and easily transportable anywhere. They are a good way of making the image and message of the candidate available to voters (Simões $e t$ al., 2009, p.53). This means, together with stickers and gifts, can create a rapprochement between the candidates and the citizens, though them politicians can introduce themselves and spread their message. However, promotional gifts are expensive and cause noise at the time of distribution, with citizens completely ignoring the message (Canavilhas, 2010, p.6)

\subsection{Web 2.0: new political communication devices}

With the emergence of the Internet, new devices have been developed and are used daily by us. These devices began to be used in the service of politics from the 90's of the twentieth century: initially, they served only to publicize the electoral programs; today, we find new contents and new applications. Given these changes, we can affirm, according to Canavilhas (2010), that nowadays the online devices bring together almost all the characteristics of traditional devices, allowing direct or indirect access, assuming any format and having a global audience without losing the possibility of personal contact (Canavilhas, 2010, p.6). In fact, the new devices are an amalgam of everything that man has ever invented to communicate with each other (Neder, 2001, p.23).

These new devices are part of the so-called Web 2.0. We can understand that the

Web 2.0 is a collection of open-source, interactive and user-controlled online applications expanding the experiences, knowledge and market power of the users as participants in business and social processes. Web 2.0 applications support the creation of informal users' networks facilitating the flow of ideas and knowledge by allowing the efficient generation, dissemination, sharing and editing/refining of informational content. (Constantinides \& Fountain, 2008, pp.232-233).

Researchers divide Web 2.0 into five categories: blogs, social networks, communities, forums and content aggregators (Constantinides \& Fountain, 2008, p.233). We cannot forget also the importance of the sites, as nowadays it is common for any institution to have an Internet page where all information is available, marking its own existence in the world (Rodrigues, 2010, p.73). Political organizations are no exception, so political sites can be considered as promotional information spaces (Rodrigues, 201, p.73). In Portugal, political sites have been growing, as the population that accesses the Internet has also been increasing. Portuguese political parties are already beginning to explore the potential of the Web, making the electoral campaigns more interactive and

1. From the French acronym MUPI, from "Mobilier Urbain pour l'Information", MUPI is an exhibitor generally protected by a glass, sometimes provided with interior lighting and with an engine that allows the rotation of advertisements, which is placed in conspicuous places, for advertising, maps and other useful information. 
participatory (Rodrigues, 2010, pp.73-74). It is natural for the parties to make use of this new tool, which is the Internet, since it is a different way from the ones previously used. Rodrigues (2010) points out four characteristics of the Internet that evidence it in relation to other means of communication (Rodrigues, 2010, p.75):

- Unlike traditional media, where the message is received in a linear way, the Internet allows users to choose the path they want to follow. There can be made efforts in order to everyone can grasp the message, even members of the population with "low digital literacy"(Rodrigues, 2010, p.75);

- The source of information is important to understand the personality of the speaker, that is, who produces the message (Rodrigues, 2010, p.75), and who in this case will be a candidate;

- The contents are available at any time, so the user can consult them when he / she wants. In this way, we can affirm that the reception time of the message is more flexible compared to the traditional media (Rodrigues, 2010, p.75);

- The Internet has created a virtual community, since in this space there are no physical barriers that exist in traditional media (Rodrigues, 2010, p.76).

These characteristics obviously have implications for political life and democracy. Barnett (1997) also enumerates four implications that the Internet may have on democracy (Barnett, 1997, p.204):

- A virtually unlimited amount of information can be made available: debates, speeches, statistical information, etc. In theory, there is no limit to the information a citizen can access;

- All citizens can communicate with each other, potentially. Communication is not limited to a particular area, but it is done globally. Spatial and temporal barriers are eliminated, so that any interested citizen can exchange points of view;

- Access to information can be done at any time, when citizens want it. This access can be done through various means (television, computer or mobile phone, for example), which can make the communication completely interactive;

- Access to information can be universal, if citizens are connected to the network.

These four aspects can bring benefits and encourage citizens to participate in politics, as much more information can be made available, instantaneously: the exchange of ideas will be encouraged and this exchange of ideas can be done among any number of participants; citizen participation is encouraged because of easy access to decision-making processes; and citizens can ask for clarifications on the most diverse issues, for example, by requesting documents (Barnett, 1997, pp.205-206). However, there are some difficulties in achieving these benefits. Barnett (1997) highlights the following:

- The new media must be available to all, in order to have an impact on democracy (Barnett, 1997: 207);

- Even if there is universal access, it must be borne in mind that if the information available is only in the hands of a restricted group this will have an impact on the type of material offered (Barnett, 1997, p.208); 
- Access to Internet may not be equal for all, for economic and demographic reasons (Barnett, 1997, p.209).

Thus, it is concluded that the Internet is a medium increasingly used by politicians for being very flexible, allowing to disseminate information in different ways, accessible through different means and available at any time. However, we must not forget that some problems may prevent citizens from accessing the content available, so that situations of inequality can appear.

\subsection{Digital democracy and political participation}

The Internet is seen as a way to make citizens' participation in politics possible, which proves that there are, in fact, ways for voters to have a word to say. We live then in the so-called "digital democracy", which, according to Wilson Gomes (2005), refers to the experience of the Internet and compatible devices, all of them aimed at increasing the potential of civil participation in conducting public affairs (Gomes, 2005, p.217).

In fact, the Internet can be a platform for an interactive policy that encourages political participation and promotes decision-making outside the politicians' sphere. On the other hand, we must keep in mind that the Internet, like any technological innovation, is shaped by its users and by how it is used (Sey \& Castells, 2004, p.363).

Gomes (2005) argues that the Internet is a great way to promote public discussion of various topics, but he warns that it is not known the impacts that the transference of decisions to citizens could have on the public sphere (Gomes, 2005, p.219). But if the Internet is recognized as such a good way to promote political discussion, how can it be explained that electoral campaigns do not translate into a more open participation process? This question is raised by Sey \& Castells (2004), who say that politicians have been "apprehensive"about the potential of the Internet. According to the authors, politicians recognize the usefulness of the Internet but they are afraid that engaging deeply the public in political processes will be time-consuming and will corrode representative democracy (Sey \& Castells, 2004, p.366).

Expressions such as "digital democracy", "electronic democracy"and "cyber democracy"have been used by researchers in the area of political communication, bringing with them huge expectations regarding the renewal of the possibilities of democratic participation. This discussion is linked to the interest in the possibilities that new technologies can bring, since these means can be constituted as a new environment of political communication and can overcome the democratic deficit of the traditional means of communication (Ferreira, 2010, pp.99-100). In fact, it is notorious that Internet allows the achievement of new activities, such as the use of blogs and social networks, which may increase the democratic practices (Gibson, 2008, p.289). This relationship between Internet and democratic practices is related to the need for information. After all, as Ferreira (2010) states the more information available and more individuals can consider the arguments and claims of others, the more they can gradually modify their original points of view (Ferreira, 2010, p.101).

The Internet is a tool that makes easier and cheaper to communicate, which is interesting in the eyes of some segments of society, such as young people and those who are at home, due to illness or some kind of disability, for example. Communication is done without spatial and tem- 
poral barriers (Polat, 2005, p.443). As such, the Internet allows people to gain more knowledge about political issues, but this will only materialize if citizens have an interest in collecting relevant information and if they have ways of interpreting that information. Polat (2005) argues that access to new technologies is not enough to automatically increase political participation, but it is important that everyone can use the Internet in order to increase participation (Polat, 2005, p.442). The author also says that the Internet is mostly used, in terms of political participation, for contacts through e-mail and for the expression of personal opinions, through online voting. This medium is particularly useful when distance is a problem for citizens, as there are groups that are widely dispersed and others that cannot move easily. Polat (2005) concludes that the potential of the Internet to influence political participation is greater in certain modes of political participation (such as online questionnaires and contacting political representatives electronically) and in certain groups of people (such as those who are geographically dispersed, those who share interests and concerns in common and those who cannot leave home easily) (Polat, 2005, pp.446-447).

But why do people participate in public life? After establishing that the Internet is a fundamental means to promote the active participation of citizens in politics, it is important to realize the motivations that lead voters to want to be part of politics. Danah Boyd (2008) indicates several reasons: identity development, community maintenance, civic engagement, among others. However, as far as social network users are concerned, people are more concerned with other activities than acting collectively (Boyd, 2008, p.112). Boyd (2008) also adds that people use social networking just to get in touch with friends they already know, because that's the purpose of these tools: being about "me and my friends."Boyd (2008) explains that users have stopped using online tools, such as chats and forums, to discuss issues with strangers. In social networks we are exposed to what our 'friends' decide to share and we only share those contents if they interest us, which can influence the scope of certain subjects (Boyd, 2008, pp.114-115). Despite this shift in the way people use the Internet to discuss issues with other people; social networks have one big advantage: the scale they can reach. There is the awareness that social networks allow the message to reach a large number of people without this costing more, since the cost of talking to 10 people is the same as talking to millions. However, it should be noted that even with the possibility of reaching a large number of individuals it does not mean that this will actually happen. On the other hand, a message that was initially intended for a small group of people can spread and reach a large group (Boyd, 2008, p.114).

There is a great deal of heterogeneity between the points of view presented online, since Internet users come from different social classes, ethnic minorities, different gender, religious and other groups previously with less visibility and access to the media. In this way, the Internet is an important tool as it can eliminate inhibition factors related to difference, but also induce the demand for conformity and agreement, which leads people to look for other individuals with which they agree. It is natural this happen, as there is a tendency for divergent opinions not to be well accepted online. Whoever has a different opinion tends to be ignored, leading eventually to give up and abandoning discussion groups. In fact, online discussions, while promoting greater participation, end up being dominated by a restricted group, as is the case with political discussions in general (Ferreira, 2010, pp.106-108). 


\section{Methodology}

This research is an exploratory study that aims to demonstrate how the use of the Internet to make political communication increases the political participation of citizens. Thus, the research problem of this study is: "Do citizens see political communication on the Internet as facilitating the political participation of the electorate, especially during the electoral period of the Portuguese legislative elections in 2015?"To answer this research question, we have outlined the following objectives: (1) to inquire whether the electorate had contact with the political information/communication shared via the Internet; (2) assess which political communication devices / platforms respondents preferred; and (3) ascertain whether respondents see the Internet, especially social networks, as a facilitator for political participation. As an exploratory study, an online questionnaire was applied between October 7 and 26, 2015 (right after the elections). The sample, selected for convenience, consists of 550 people, aged between 16 and 87 years, mostly from Portugal and with higher education. About two thirds of the respondents are male, which translates into 367 respondents, corresponding to $66.73 \%$ of the total. The remaining individuals who answered the questionnaire are female, accounting for 183 women, $33.27 \%$ of the value obtained.

\section{ANALysis AND Discussion Of Results}

Taking into account our research problem and the objectives outlined, the first results obtained are related to the monitoring of the electoral campaign on the Internet for the 2015 Legislative Elections. Although our sample claims to have current access to the Internet, it was verified that only 268 individuals $(48.73 \%$ ) stated that they followed the electoral campaign for those elections through the Internet, with 282 people (51.27\% of the respondents) answered not having followed the electoral campaign through the Internet, despite having access to this tool (Table 1). So, in spite of the growing importance of internet, there are a great number of people that did not use it for political reasons during the electoral campaign.

Table 1. Number of respondents who followed the electoral campaign for the 2015 Legislative Elections via Internet. (Self-elaboration)

Did you follow the electoral campaign for the 2015

Legislative Elections via the Internet (social networks and / or party-created websites specifically for this purpose)?

\begin{tabular}{ccc}
\hline Response & Yes & No \\
Total & 268 & $\mathbf{2 8 2}$ \\
Percentage & $48,73 \%$ & $\mathbf{5 1 , 2 7 \%}$ \\
\hline
\end{tabular}

When questioned about the means used to monitor the 2015 legislative elections via Internet, respondents chose very clearly the Social Networks option (195 people, corresponding to $72.76 \%$ ). The second most voted option was Sites (110 respondents, equivalent to 41.04\%), with 36 people $(13.43 \%)$ saying that they did not use any platform to follow the electoral campaign (Table 2). In fact, these results underline the importance of social networks to political communication. 
Table 2. Means to follow the electoral campaign for the 2015 Legislative Elections. (Self-elaboration)

\begin{tabular}{cccc}
\multicolumn{3}{c}{ Though what means did you follow the electoral Campaign } \\
\multicolumn{2}{c}{ for the } & 2015 & Legislative Elections on the Internet? \\
\hline Responses & Sites & Social networks & Neither \\
Total & 110 & $\mathbf{1 9 5}$ & 36 \\
Percentage & $41,04 \%$ & $\mathbf{7 2 , 7 6 \%}$ & $13,43 \%$ \\
\hline
\end{tabular}

Next, we explore which were the social networks most used by the respondents to follow the political parties during the legislative elections of 2015. Faced with the options Facebook, Twitter, Youtube, Flickr, Instagram and 'None', most of the answers of the respondents focused on the hypothesis Facebook, chosen by 214 people (79.85\%). This result is not unrelated to the fact that Facebook is the social network with more users. The 'None' option was the choice of 47 individuals (17.54\%), registering a percentage higher than all social networks, except for Facebook. The remaining social networks are in the following order of preference: YouTube and Twitter (34 people each, corresponding to 12.69\%), Instagram (16 respondents, equivalent to $5.97 \%$ ) and Flickr (2 people, the corresponding to 0.75\%) (Table 3).

Table 3. Social networks used to follow the political parties. (Self-elaboration)

Through what social networks did you follow the political parties during the electoral campaign for the 2015 Legislative Elections?

\begin{tabular}{ccccccc}
\hline Responses & Facebook & Twitter & Youtube & Flickr & Istagram & Neither \\
Total & $\mathbf{2 1 4}$ & 34 & 34 & 2 & 16 & 47 \\
Percentage & $\mathbf{7 9 , 8 5 \%}$ & $12,69 \%$ & $12,69 \%$ & $0,75 \%$ & $5,97 \%$ & $17,54 \%$ \\
\hline
\end{tabular}

From here, we try to investigate the extent to which respondents view social networks as facilitating political participation. The results are based on ten statements about the relationship between social networks and political issues. Respondents had to decide whether or not they agree with the assertion by choosing a number between 1 and 10 on a scale, where 1 represent weak agreement and 10, a strong agreement.

As regards affirmation 1 - "Social networks lead voters to become closer to political parties", responses with values 5 and 6 (79 individuals, 14.36\%) were the most chosen by the respondents, followed by options 8 (77 individuals, 14\%) and 7 (74 individuals, 13.45\%), indicating that respondents strongly agree with the statement. In all, these four hypotheses make up $56.17 \%$ of the respondents, corresponding to 309 people. Fewer chosen were the values that indicated a maximum agreement, with option 9 being selected by 22 people (4\%) and 10 by 24 people $(4.36 \%)$ (Table 4). 
Table 4. Level of agreement with the sentence "Social networks lead voters to become closer to political parties". (Self-elaboration)

\begin{tabular}{cccccccccccc}
\multicolumn{10}{c}{ Social networks lead voters to become closer to political parties. } \\
\hline Responses & 1 & 2 & 3 & 4 & 5 & 6 & 7 & 8 & 9 & 10 \\
Total & 50 & 32 & 65 & 48 & $\mathbf{7 9}$ & $\mathbf{7 9}$ & $\mathbf{7 4}$ & $\mathbf{7 7}$ & 22 & 24 \\
Percentage & $9,09 \%$ & $5,82 \%$ & $11,82 \%$ & $8,73 \%$ & $\mathbf{1 4 , 3 6 \%}$ & $14,36 \%$ & $\mathbf{1 3 , 4 5 \%}$ & $\mathbf{1 4 , 0 0 \%}$ & $4,00 \%$ & $4,36 \%$ \\
\hline
\end{tabular}

As with the first statement, also the statement 2 - "Social networks contribute to greater political participation- presented a high level of agreement, with the numbers 6 (74 people, $13.45 \%$ ), 7 (99 people , 18\%) and 8 ( 8 persons, $15.45 \%$ ) were the most chosen by the respondents. In total, $46.9 \%$ of the respondents chose these three options, corresponding to 258 of 550 respondents. The least chosen hypothesis was 9 , with $4.91 \%$, followed by 10 , with $5.64 \%$, indicating that, again, the values that indicate a maximum agreement were the least chosen. The values indicating a poor agreement, between 1 and 5, registered values between 6\% (number 2) and 9,82\% (number 3) (Table 5).

Table 5. Level of agreement with the sentence "Social networks contribute to greater political participation". (Self-elaboration)

\begin{tabular}{cccccccccccc}
\multicolumn{10}{c}{ Social networks contribute to greater political participation. } \\
\hline Responses & 1 & 2 & 3 & 4 & 5 & 6 & 7 & 8 & 9 & 10 \\
Total & 49 & 33 & 54 & 49 & 49 & $\mathbf{7 4}$ & $\mathbf{9 9}$ & $\mathbf{8 5}$ & 27 & 31 \\
Percentage & $8,91 \%$ & $6,00 \%$ & $9,82 \%$ & $8,91 \%$ & $8,91 \%$ & $\mathbf{1 3 , 4 5 \%}$ & $18,00 \%$ & $15,45 \%$ & $4,91 \%$ & $5,64 \%$ \\
\hline
\end{tabular}

The third statement - "Social networks contribute to a more active role of citizens in politics"presented a high level of agreement on the part of the respondents, with the most relevant values being the same as those related to statement 2: 6 (78 people, 14.18\%), 7 (97 people, 17.64\%) and 8 (80 people, $14.55 \%$ ). Respondents who chose these options account for $46.37 \%$ of the total responses. Again, the least selected responses corresponded to a very high agreement, $9(5.64 \%)$ and $10(4.73 \%)$. The values corresponding to a low level of agreement, between 1 and 5, were selected among $6.91 \%$ (number 4 ) and $11.27 \%$ (number 3 ) of the respondents (Table 6).

Table 6. Level of agreement with the sentence "Social networks contribute to a more active role of citizens in politics". (Self-elaboration)

\begin{tabular}{ccccccccccc}
\multicolumn{10}{c}{ Social networks contribute to a more active role of citizens in politics. } \\
\hline Responses & 1 & 2 & 3 & 4 & 5 & 6 & 7 & 8 & 9 & 10 \\
Total & 44 & 40 & 62 & 38 & 54 & $\mathbf{7 8}$ & $\mathbf{9 7}$ & $\mathbf{8 0}$ & 31 & 26 \\
Percentage & $8,00 \%$ & $7,27 \%$ & $11,27 \%$ & $6,91 \%$ & $9,82 \%$ & $\mathbf{1 4 , 1 8 \%}$ & $\mathbf{1 7 , 6 4 \%}$ & $\mathbf{1 4 , 5 5 \%}$ & $5,64 \%$ & $4,73 \%$ \\
\hline
\end{tabular}

The statement "Social networks promote greater dialogue on politics", similar to the previous ones, presented a high level of agreement on the part of the people interviewed. The most chosen values were 7 and 8 , by $14.91 \%$ ( 82 people) and $21.27 \%$ (117 people) of the respondents, respectively. In this case, the least selected values were indicative of low levels of agreement. The 
numbers from 1 to 5 were chosen between 5.09\% (number 2) and 9.09\% of the respondents. The values that refer to a higher degree of agreement were chosen by $9.82 \%$ (value 9) and $9.27 \%$ (value 10) of the subjects surveyed (Table 7).

Table 7. Level of agreement with the sentence "Social networks promote greater dialogue on politics". (Self-elaboration)

\begin{tabular}{cccccccccccc}
\multicolumn{10}{c}{ Social networks contribute to a more active role of citizens in politics. } \\
\hline Responses & 1 & 2 & 3 & 4 & 5 & 6 & 7 & 8 & 9 & 10 \\
Total & 34 & 28 & 41 & 33 & 50 & 60 & $\mathbf{8 2}$ & $\mathbf{1 1 7}$ & 54 & 51 \\
Percentage & $6,18 \%$ & $5,09 \%$ & $7,45 \%$ & $6,00 \%$ & $9,09 \%$ & $10,91 \%$ & $\mathbf{1 4 , 9 1 \%}$ & $\mathbf{2 1 , 2 7 \%}$ & $9,82 \%$ & $9,27 \%$ \\
\hline
\end{tabular}

The statement "Social networks contribute to a decrease in the abstention rate"was the first to show a low degree of agreement on the part of the respondents, since the values most frequently selected were 1 (by 104 people, corresponding to 18,91\%) and 3 (by 107 people, corresponding to $19.45 \%)$. In all, these two hypotheses were chosen by 211 respondents $(38.36 \%)$. The lowest values corresponded to a high agreement: 7 (7.27\%), 8 (4.36\%), $9(1.64 \%)$ and $10(1.09 \%)$. The remaining values were chosen by between $10.73 \%$ (numbers 2 and 4 ) and $14.36 \%$ of the respondents (number 5) (Table 8).

Table 8. Level of agreement with the sentence "Social networks contribute to a decrease in the abstention rate". (Self-elaboration)

\begin{tabular}{ccccccccccccc}
\multicolumn{10}{c}{ Social networks contribute to a decrease in the abstention rate. } \\
\hline Responses & 1 & 2 & 3 & 4 & 5 & 6 & 7 & 8 & 9 & 10 \\
Total & $\mathbf{1 0 4}$ & 59 & $\mathbf{1 0 7}$ & 59 & 79 & 63 & 40 & 24 & 9 & 6 \\
Percentage & $\mathbf{1 8 , 9 1 \%}$ & $10,73 \%$ & $\mathbf{1 9 , 4 5 \%}$ & $10,73 \%$ & $14,36 \%$ & $11,45 \%$ & $7,27 \%$ & $4,36 \%$ & $1,64 \%$ & $1,09 \%$ \\
\hline
\end{tabular}

The sixth statement, unlike the first five, did not present general analysis values close to each other. There are the numbers 1 (chosen by 73 people, corresponding to 13.27\%), 5 (selected by 71 individuals, corresponding to $12.91 \%$ ) and 7 (the value with a more significant percentage, chosen by 85 people, corresponding to $15.45 \%$ ). In order to understand the level of agreement of respondents to this statement, it is important to also analyse the value 6 , intermediate number between those already analysed 5 and 7 , the closest to the three highlighted values. The number 6 was chosen by 65 people, the equivalent of $11.82 \%$ of respondents, and it seems like the fourth most chosen hypothesis. Therefore, it is verified that values 5, 6 and 7 were chosen by $40.18 \%$ of respondents, so we can say that the agreement with this assertion is moderate (Table 9).

Table 9. Level of agreement with the sentence "Social networks contribute to a better understanding of the electoral program of the political parties". (Self-elaboration)

\begin{tabular}{ccccccccccc}
\multicolumn{10}{c}{ Social networks contribute to a more active role of citizens in politics. } \\
\hline Responses & 1 & 2 & 3 & 4 & 5 & 6 & 7 & 8 & 9 & 10 \\
Total & $\mathbf{7 3}$ & 44 & 57 & 48 & $\mathbf{7 1}$ & 65 & $\mathbf{8 5}$ & 57 & 27 & 23 \\
Percentage & $\mathbf{1 3 , 2 7 \%}$ & $8,00 \%$ & $10,36 \%$ & $8,73 \%$ & $\mathbf{1 2 , 9 1 \%}$ & $11,82 \%$ & $\mathbf{1 5 , 4 5 \%}$ & $10,36 \%$ & $4,91 \%$ & $4,18 \%$ \\
\hline
\end{tabular}


The situation in relation to statement 7 is very similar to that found in relation to statement 6: one among the numbers most chosen by the respondents is quite distant from the others. The numbers to be highlighted are 5 ( 89 people, 16.18\%), 6 (selected by 78 individuals, equivalent to $14.18 \%$ ), 7 (selected by 76 people, corresponding to $13.82 \%$ ) and, far from all these values, 1 (hypothesis chosen by 75 individuals, equivalent to 13.64\%). Values 5, 6 and 7 were selected by $44.18 \%$ of respondents; we can say that the agreement with this statement is moderate. The values less chosen by the respondents were $9(2.55 \%)$ and $10(2.36)$, numbers, that indicate a maximum agreement with the sentence presented. The remaining values had percentages between $8.91 \%$ (numbers 2 and 4 ) and $10.55 \%$ (number 3 ) (Table 10).

Table 10. Level of agreement with the sentence "Social networks increase voters' interest in politics". (Self-elaboration)

\begin{tabular}{ccccccccccc}
\multicolumn{10}{c}{ Social networks increase voters' interest in politics. } \\
\hline Responses & 1 & 2 & 3 & 4 & 5 & 6 & 7 & 8 & 9 & 10 \\
Total & $\mathbf{7 5}$ & 49 & 58 & 49 & $\mathbf{8 9}$ & $\mathbf{7 8}$ & $\mathbf{7 6}$ & 49 & 14 & 13 \\
Percentage & $\mathbf{1 3 , 6 4 \%}$ & $8,91 \%$ & $10,55 \%$ & $8,91 \%$ & $\mathbf{1 6 , 1 8 \%}$ & $\mathbf{1 4 , 1 8 \%}$ & $\mathbf{1 3 , 8 2 \%}$ & $8,91 \%$ & $2,55 \%$ & $2,36 \%$ \\
\hline
\end{tabular}

Respondents are strongly in agreement with the statement "Social networks allow voters to exchange ideas on political issues", as the most chosen numbers were 7 (by 93 people, or $16.91 \%$ ) and the 8 (per 100 individuals, the equivalent of $18.18 \%$ ). In fact, more than one third of the people surveyed (35.09\%) opted for these values. Also chosen were the values that refer to a maximum agreement: 9 (72 people, 13.09\%) and 10 (67 people, 12.18\%). Options from 1 to 5 were the least selected, representing percentages of the sample between $3.82 \%$ (number 4 ) and $9.64 \%$ (number 6) (Table 11).

Table 11. Level of agreement with the sentence "Social networks allow voters to exchange ideas on political issues". (Self-elaboration)

\begin{tabular}{ccccccccccc}
\multicolumn{10}{c}{ Social networks allow voters to exchange ideas on politics issues. } \\
\hline Responses & 1 & 2 & 3 & 4 & 5 & 6 & 7 & 8 & 9 & 10 \\
Total & 29 & 26 & 47 & 21 & 42 & 53 & $\mathbf{9 3}$ & $\mathbf{1 0 0}$ & 72 & 67 \\
Percentage & $5,27 \%$ & $4,73 \%$ & $8,55 \%$ & $3,82 \%$ & $7,64 \%$ & $9,64 \%$ & $\mathbf{1 6 , 9 1 \%}$ & $\mathbf{1 8 , 1 8 \%}$ & $13,09 \%$ & $12,18 \%$ \\
\hline
\end{tabular}

Respondents showed a low level of agreement with statement 9 - "social networks allow voters to get answers to their questions directly from the political parties", since the most chosen values were 1 (103 people, corresponding to $18.73 \%$ ), 2 ( 82 people, equivalent to $14,91 \%$ ) and 3 (selected by 78 people, corresponding to $14.18 \%$ ). In total, 263 respondents (47.82\%) opted for these hypotheses. The least chosen numbers were those that sent a maximum agreement, 9 (1.64\%) and $10(2.36 \%)$. The remaining options were the choice between $5.09 \%$ and $13.09 \%$ of respondents (Table 12). 
Table 12. Level of agreement with the sentence "Social networks allow voters to get answers to their questions directly from the political parties". (Self-elaboration)

\begin{tabular}{cccccccccccc}
\multicolumn{10}{c}{ Social networks contribute to a more active role of citizens in politics. } \\
\hline Responses & 1 & 2 & 3 & 4 & 5 & 6 & 7 & 8 & 9 & 10 \\
Total & $\mathbf{1 0 3}$ & $\mathbf{8 2}$ & $\mathbf{7 8}$ & 65 & 72 & 59 & 41 & 28 & 9 & 13 \\
Percentage & $\mathbf{1 8 , 7 3 \%}$ & $\mathbf{1 4 , 9 1 \%}$ & $\mathbf{1 4 , 1 8 \%}$ & $11,82 \%$ & $13,09 \%$ & $10,73 \%$ & $7,45 \%$ & $5,09 \%$ & $1,64 \%$ & $2,36 \%$ \\
\hline
\end{tabular}

The results obtained with respect to the tenth statement "Social networks allow voters to contact parties more easily"were widely dispersed in the analysis by variables, but there are two options that are very close to emphasizing in the general analysis. Values 1 (78 people, corresponding to $14.18 \%$ ) and 3 (77 respondents, equivalent to $14 \%$ ) were the most frequently chosen by the respondents, indicating a low agreement with this sentence. The greater the number presented in the scale, the smaller the percentage of respondents who opted for this hypothesis. Thus, it was found that the less chosen values were once again $9(4.55 \%)$ and $10(4.36 \%)$. The number 2 , intermediate value between the two most chosen by the members of the sample, was the option for $10.73 \%$ of the respondents. The remaining values were between $7.27 \%$ (number 8 ) and $11.82 \%$ (number 5) of the respondents (Table 13).

Table 13. Level of agreement with the sentence "Social networks allow voters to contact political parties more easily". (Self-elaboration)

\begin{tabular}{cccccccccccc}
\multicolumn{10}{c}{ Social networks allow voters to contact political parties more easily. } \\
\hline Responses & 1 & 2 & 3 & 4 & 5 & 6 & 7 & 8 & 9 & 10 \\
Total & $\mathbf{7 8}$ & 59 & $\mathbf{7 7}$ & 64 & 65 & 67 & 51 & 40 & 25 & 24 \\
Percentage & $\mathbf{1 4 , 1 8 \%}$ & $10,73 \%$ & $\mathbf{1 4 , 0 0 \%}$ & $11,64 \%$ & $11,82 \%$ & $12,18 \%$ & $9,27 \%$ & $7,27 \%$ & $4,55 \%$ & $4,36 \%$ \\
\hline
\end{tabular}

\section{Conclusions}

From the results obtained, we can conclude that, although political parties made great use of the Internet during the electoral campaign for the legislative elections of 2015 (since they used several platforms as sites and social networks), the respondents mainly used the Facebook to follow the political parties. It can also be concluded that respondents agree that social networks bring voters closer to political parties, contribute to greater political participation, contribute to a more active role of citizens in politics, promote greater dialogue on political issues and allow voters to exchange ideas on political issues. Thus, we confirm that respondents indicated a higher level of agreement on statements about citizen dialogue on political issues, increased political participation and proximity between political parties and voters. However, respondents were not convinced that social networks contribute to a better understanding of the electoral program of the different political parties and they do not increase voter interest in politics. Likewise, although communication through Internet is easier, respondents do not believe that social networks allow voters to get answers to their questions or easily contact to political parties. Respondents also consider that social networks do not contribute to reducing the abstention rate. These last results 
contradict many of the ideas presented by some researchers about the importance of the Internet for political communication and for the reduction of electoral abstention.

\section{REFERENCES}

Barnett, S. (1997). New media, old problems: new technology and the political process. European Journal of Communication, 12 (2): 193-218. Doi: 10.1177/0267323197012002003.

Boyd, D. (2008). Can social networks sites enable political action?. Rebooting America: 112-116. Retrieved from www.danah.org/papers/Rebooting_America.pdf

Canavilhas, J. (2010). A comunicação política na era da internet. BOCC-Biblioteca On-Line de Ciências da Comunicação: 1-12. Retrieved from hrefhttp://www.bocc.ubi.pt/pag/canavilhasjoao-comunicacao-politica-na-era-da-internet.pdfwww.bocc.ubi.pt/pag/canavilhas-joao-com unicacao-politica-na-era-da-internet.pdf

Constantinides, E. \& Fountain, S. J. (2008). Web 2.0: conceptual foundations and marketing issues. Journal of Direct, Data and Digital Marketing Practice, 9 (3): 231-244. Doi: 10.1057/palgrave.dddmp.4350098.

Ferreira, G. (2010). Internet e deliberação - a discussão política em fóruns online. Media \& Jornalismo, (16): 99-114. Retrieved from http://fabricadesites.fcsh.unl.pt/polocicdigital/wpcontent/uploads/sites/8/2017/03/16artigo6.pdf

Gibson, R. K. (2008). New media and the revitalisation of politics. Revitalising Politics Conference: 289-299. Doi: 10.1080/00344890903129566.

Gomes, W. (2005). A democracia digital e o problema da participação civil na decisão política. Fronteiras-Estudos Midiáticos: 214-222.

Hacke, K. L. \& Dijk, J. V. (2000). Digital democracy: issues of theory and practice. London, UK: Sage Publications.

Neder, C. P. (2001). As influências das novas tecnologias de comunicação social na formação política. BOCC - Biblioteca On-Line de Ciências da Comunicação. Retrievde from www.bocc.ubi.pt/pag/neder-cristiane-novas-tecnologias.pdf

Polat, R. K. (2005). The internet and political participation: exploring the explanatory links. European Journal of Communication, 20 (4): 435-459. Doi: 10.1177/0267323105058251.

Rieffel, R. (2003). Sociologia dos media. Porto: Porto Editora.

Rodrigues, R. (2009). Ciberpolítica: comunicação política 2.0 nas eleições legislativas de 2009. Covilhã: Universidade da Beira Interior.

Rodrigues, R. (2010). Interactividade e novas estratégias nas eleições legislativas de 2009. Revista Rhêtorikê, Junho: 73-94. Retrieved from www.rhetorike.ubi.pt/03/pdf/Rhetorike03interactividade.pdf

Sepúlveda, A. J. (2000). Marketing político na internet. Matosinhos: Centro Atlântico. 
Sey, A. \& Castells, M. (2004). From media politics to networked politics: the internet and the political process. The Network Society a Cross-Cultural Perspective: 363-381. Doi: 10.4337/9781845421663.00030.

Simões, M. M.; Antunes, M. D.; Cunha, J. P.; Marques, A.; Lopes,C. \& Beirão, I. (2009). Marketing e comunicação política. Lisboa: Edições Sílabo.

Sorj, B. (2006). Internet, espaço público e marketing político. Novos Estudos, November, 123136. Doi: 10.1590/S0101-33002006000300006. 